\title{
A PERSONALIDADE DO PROFESSOR NA PERSPECTIVA HISTÓRICO- CULTURAL.
}

MARTINS, L. M. A formação social da personalidade do professor: um enfoque vigotskiano. Campinas: Autores Associados, 2007.

Resenhado por:

Saulo Rodrigues de Carvalho ${ }^{1}$

Nos últimos anos o professor tem sido alvo de inúmeras pesquisas a respeito da sua atividade e de sua relação com a docência. Muitas dessas pesquisas tendem a descrever e até mesmo moldar sua personalidade encetada em processos deterministas e adaptativos, que coincidem com as formas de subordinação do homem à alienação do trabalho.

$\mathrm{Na}$ direção oposta aos modelos pré-estabelecidos de personificação do professor a obra de Ligia Márcia Martins, trás a perspectiva histórica e cultural da personalidade, retratando desta maneira sua concretude enquanto síntese objetiva de múltiplas determinações, que não se encerra em si mesma, mas que se realiza no constante processo de "auto-realização do indivíduo ante a estrutura histórico social que o sustenta" (MARTINS, 2007, p.126). Isto significa que a personalidade não é uma condição dada pela natureza ao homem, mas sim um produto da criação humana na incessante e vital relação de transformação da natureza.

A professora Lígia Márcia Martins é livre docente pela Universidade Estadual Paulista "Júlio de Mesquita Filho" - UNESP, onde leciona para o curso de Psicologia no campus de Bauru e no Programa de Pós-Graduação em Educação Escolar em Araraquara. É mestra em Psicologia Clínica pela PUC de São Paulo e doutora em educação pela UNESP-Marília. Fruto de seus estudos teóricos sobre a categoria Personalidade, o livro que segue em destaque examina a luz do Materialismo Histórico Dialético a formação da personalidade do professor sob a égide do capitalismo.

Dividido em três capítulos o livro acentua o compromisso teórico metodológico da autora com o tema, como salientado no prefácio escrito pelo Professor Newton Duarte, enaltecendo sua postura de pesquisadora marxista no trato e na "coerência com os fundamentos teóricos, espírito crítico em relação às implicações ideológicas e vigor em relação ao método de elaboração do conhecimento e de condução consciente dos processos de pensamento" (MARTINS, 2007, p. XIV). Deste modo, temos concebidos os capítulos: "A personalidade do professor em questão", "Da concepção de homem à concepção de psiquismo" e "O processo de personalização".

No primeiro capítulo Martins faz referência às novas abordagens que tratam a questão da formação do professor na atualidade. Salienta, contudo, que tais concepções se fundamentam, sobretudo, nos aspectos direcionados ao desenvolvimento pessoal do professor. Nestes estudos “(...) As características pessoais, as vivencias profissionais, as histórias de vida, a construção da identidade etc. com maior frequência tornam-se objetos de investigação educacional (...)" (p.9). Sem negar a importância do estudo das singularidades e particularidades do trabalho do professor, destaca que as novas concepções sobre sua formação e personalidade pautadas somente na caracterização da subjetividade docente, tendem a permanecer na superfície desse conhecimento, uma vez que não se detém no entendimento das causas objetivas que levam o professor a tomar para si determinados comportamentos. 
Ao analisar a teoria do Professor Reflexivo, Martins (2007) discute a caracterização dada por essa teoria, que delineia o professor como um indivíduo perplexo diante das mudanças constantes na sociedade. Ainda sob esse aspecto, as proposições de enfrentamento à celeridade das mudanças sociais, identificadas especialmente pelas transformações no campo tecnológico e informacional, estariam circunscritas no próprio professor. Ou seja, na reflexão sobre a sua prática individual cotidiana. Martins (2007) examina que, entretanto, as "mudanças sociais", são apresentadas pela teoria do Professor Reflexivo como um elemento cristalizado e carente de analises mais profundas sobre as verdadeiras causas de sua manifestação, seus efeitos reais sobre a vida cotidiana e nexos com a atividade docente.

Embora aparentemente demonstrem preocuparem-se com a valorização do professor tais concepções subjetivistas, sobre a sua prática e personalidade estariam muito mais dispostas a “(...) preparar os indivíduos para suportar uma organização política e econômica que os aguarda estruturada sob a égide do capital (...)" (MARTINS, 2007, p.27), do que transformar verdadeiramente as condições desumanizantes que decorrem desse modelo de organização social.

O segundo capítulo de natureza teórico metodológica apresenta o escopo categorial utilizado pela autora para compreender as bases Materialistas Histórico Dialéticas da personalidade. Intitulado "Da concepção de homem à concepção de psiquismo", este capítulo discute as implicações sociológicas e psicológicas da categoria Trabalho na constituição Histórico Cultural da personalidade. Partindo da dimensão ontológica do trabalho, Martins (2007) aborda as relações entre o trabalho enquanto categoria fundante da natureza do homem dialeticamente posta nos nexos entre; "O trabalho e a consciência do homem", "O trabalho e a socialidade do homem", "O trabalho e a universalidade do homem" e o "O trabalho e a liberdade do homem". No mesmo intuito trata a questão do "trabalho alienado", e suas implicações na constituição da individualidade e personalidade do homem.

Ao visitar o complexo categorial do trabalho a autora busca "(...) solidificar a compreensão do psiquismo humano (...) na trajetória histórico social da humanidade" (MARTINS, p.7). De outro modo, descreve o processo de humanização da natureza e desenvolvimento da pisque humana. Isto é, o trabalho enquanto atividade vital e criadora transforma não só objetivamente a matéria como organiza subjetivamente a consciência dos homens sobre o mundo e sobre si mesmos.

No surgimento do psiquismo enquanto reflexo do real e da consciência, da capacidade de compreender objetivamente a realidade e de se relacionar objetivamente com ela, estão, portanto, as bases para a compreensão do processo de personalização do homem, “(...) não existindo como algo em si mesmo, como fenômeno puro, mas, sim, como pensamento de uma pessoa que possui interesses, aptidões, sentimentos, enfim, uma personalidade" (MARTINS, 2007, p.81).

Por ultimo "O processo de personalização" é o capítulo que irá tratar especificamente a categoria personalidade. Nele, Martins (2007) expõe a gênese do desenvolvimento da personalidade, lançando-se à tarefa de compreender a totalidade histórico social das bases sociais reais que sustentam a sua formação.

Desse modo estabelece a aproximação e vinculação entre a individualidade e a personalidade. Fundamentada na teoria desenvolvida pelo pesquisador soviético Aléxis N. Leontiev apresenta-nos as distinções teóricas entre essas duas categorias. A individualidade, portanto seria a "(...) síntese de peculiaridades congênitas e adquiridas (...)" (MARTINS, 2007, p. 88), posto que a personalidade seja "realizada pelas relações 
sociais que o indivíduo estabelece por meio de sua atividade (...)" (Ibid.). Dito de outra maneira, a individualidade estabelece a base para a formação da personalidade.

Ao esboçar o processo de apropriação e objetivação na formação da individualidade e do gênero humano, confere a esse ato fundamental à sociabilidade humana a qualidade de personalizar-se, de dar ao processo de individuação qualidades únicas e irrepetíveis, que "(...) representa uma objetivação da individualidade, o estilo pessoal que lhe configurar, revela-se a continuidade na mudança permanente do processo de individualização" (MARTINS, 2007, p.91).

O processo de personalização é destacado dessa forma como essencialmente social e dialeticamente posto na relação de objetivação e apropriação da produção humana universal. Quando essa relação encontra-se cindida, isto é, quando os produtos da apropriação humana correspondem somente ao mínimo necessário para a sobrevivência dos indivíduos e não à expressão da máxima genericidade dos homens, quando essa é uma relação alienada; em consequência, temos uma formação alienada da personalidade.

Apontando as condições sociais com as quais os homens constituem a sua vida na sociedade capitalista, de alienação do trabalho e subordinação à propriedade privada, Martins (2007) assinala que as condições objetivas de alienação com as quais os homens se relacionam refletem no psiquismo os aspectos das condições socioeconômicas que originam a alienação. Dessa maneira a alienação pode ser observada nos processos psicológicos manifesta sob a forma de sofrimentos psíquicos tais como os de "sentimento de falta de poder" ou "sentimento de impotência", "sentimento do absurdo", "isolamento", "auto-estranhamento" e "ausência de normas". Reitera que a personalidade alienada "(...) expressa-se como se fosse um duplo da pessoa" (MARTINS, 2007, p.133), que se converte em uma relação coisificada do sujeito com a sociedade, na assunção de papéis que as circunstâncias sociais exigem. $O$ indivíduo não entra integralmente como pessoa nas relações, senão como força de trabalho, assumindo assim em sua atividade o papel designado pelo capital na sua constituição.

O livro de Martins (2007) por sua profundidade teórica e compromisso político, torna-se, desta maneira uma leitura obrigatória para a compreensão da categoria personalidade e das condições sociais que formam a personalidade do professor na sociedade vigente. Seu mérito consiste na superação das teorias idealistas e subjetivistas da personalização, estabelecendo as bases reais e concretas, histórico-culturais, da formação de personalidade humana. Sem essa compreensão é impossível entender de fato os limites e possibilidades da formação da personalidade, nem muito menos, compreender as implicações sociais que interferem na personalidade do professor, sob as condições materiais legadas pelo capitalismo.

Consequentemente sua reflexão aponta para a formação de uma personalidade que tenha como finalidade a superação das condições de alienação e subordinação da individualidade e personalidade humanas aos desígnios do capital. Do mesmo modo a formação de um professor que dirija ativa e conscientemente sua atividade de ensino e que tome para si a tarefa de superação da sociedade alienada. 